\title{
PENGARUH PENDEMI COVID-19 TERHADAP KINERJA PERUSAHAAN (PROFITABILITAS, LIKUIDITAS, FAKTOR EKSTERNAL, DAN HARGA SAHAM) PADA PERUSAHAAN INDUSTRI OTOMOTIF DI BEI
}

\author{
Hastuti Sari Budiningsih ${ }^{1}$, Zulkifli², Widarto Rachbini ${ }^{3}$ \\ Magister Manajemen, Sekolah Pascasarjana, Universitas Pancasila ${ }^{1,2,3}$ \\ Hast.sari81@gmail.com¹, Zulkifli@univpancasila.ac.id²,Yeswid@gmail.com²
}

\begin{abstract}
This research's purpose is to determine the impact of the COVID-19 pandemic on the performance of automotive companies listed on the Indonesia Stock Exchange. In addition, this research is also conducted for determining the effect of the external factors (inflation, interest rates), liquidity (current ratio, cash ratio), profitability (ROI, ROA, NPM) and stock prices in automotive industry companies listed on the Indonesia Stock Exchange. The method used in this research is a quantitative method and uses Structural Equation Mode analysis. The sample used in this research are 5(five) automotive industry companies listed on the Indonesia Stock Exchange. The data used is quarterly financial report data of 2019 (before the COVID-19 pandemic) and 2020 (after the COVID-19 pandemic). Based on the research of the study indicate that external factors in this case inflation and interest rates have a significant positive effect on stock prices; Liquidity has a significant positive effect on profitability; Profitability has a significant positive effect on stock prices; External factors have no significant effect on stock prices; Liquidity has a significant negative effect on stock prices. The overall financial performance of automotive industry companies listed on the IDX decreased due to the COVID-19 pandemic, before the pandemic the average company performance was quite good, but with the COVID-19 pandemic the performance of the automotive industry companies decreased. A significant decrease in the level of sales resulted in a decrease in net income.
\end{abstract}

Keywords: External Factor; Liquidity; Profitability; Stock Price. 


\begin{abstract}
Abstrak
Penelitian ini bertujuan untuk mengetahui dampak pandemi COVID-19 terhadap kinerja perusahaan industri otomotif yang terdaftar di BEI. Selain itu, penelitian ini bertujuan untuk mengetahui pengaruh faktor eksternal (inflasi, suku bunga), likuiditas (current rasio, cash rasio), profitabilitas (ROI, ROA, NPM) dan harga saham pada perusahaan industri otomotif yang terdaftar di BEI. Metode yang digunakan dalam penelitian ini adalah metode kuantitatif dan menggunakan analisis SEM PLS. Sampel yang digunakan dalam penelitian ini adalah 5 perusahaan industri otomotif yang terdaftar di BEI. Data yang digunakan adalah data laporan keuangan triwulan tahun 2019 (sebelum pandemi COVID19) dan 2020 (setelah pandemi COVID-19). Berdasarkan hasil penelitian menunjukkan bahwa Faktor Eksternal dalam hal ini inflasi dan suku bunga berpengaruh positif signifikan terhadap harga saham; Likuiditas berpengaruh positif signifikan terhadap profitabilitas; Profitabilitas berpengaruh positif signifikan terhadap harga saham; Faktor eksternal tidak berpengaruh signifikan terhadap harga saham; Likuiditas berpengaruh negatif signifikan terhadap harga saham. Kinerja keuangan perusahaan otomotif yang terdaftar di BEI secara keseluruhan menurun akibat pandemi COVID-19, jika sebelum pandemi rata-rata kinerja perusahaan cukup baik, namun dengan adanya pandemi COVID19 kinerjanya perusahaan industry otomotif menurun. Penurunan tingkat penjualan yang signifikan mengakibatkan penurunan laba bersih.
\end{abstract}

Kata Kunci: Faktor Eksternal; Likuiditas; Profitabilitas; Harga Saham.

\title{
Pendahuluan
}

Dalam beberapa tahun terakhir, industri otomotif nasional menunjukkan perkembangan yang terbilang atraktif. Ini merupakan bagian dari imbas positif pertumbuhan jumlah kelas menengah Indonesia selama satu dasawarsa terakhir. Bank Dunia menyebut, jumlah kelas menengah pada 2002 hanya mencapai tujuh persen dari total penduduk Indonesia. Jumlah itu melonjak signifikan pada 2017 menjadi 22 persen (Amri \& Ramdani, 2020).

Pada 2018 Bank Dunia melaporkan jumlah kelas menengah Indonesia menembus 30 persen. Sementara itu, terdapat 120 juta penduduk lainnya tergolong sebagai aspiring middle class atau kelas menengah. Harapan mereka ini adalah kelompok yang tak lagi miskin dan sedang beranjak menuju ke kondisi ekonomi yang lebih mapan (Amri et al., 2021).

Bank Dunia memprediksikan jumlah kelas menengah Indonesia pada tahun 2050 nanti akan mencapai 143 juta orang atau lebih dari 50 persen dari total jumlah penduduk. Merujuk pada kriteria Bank Dunia, kelas menengah adalah kelompok masyarakat dengan pengeluaran per hari antara 2 sampai 20 dolar Amerika Serikat (AS). Keberadaan kelas menengah dianggap penting dalam pertumbuhan ekonomi lantaran merupakan elemen utama penggerak roda produksi dan konsumsi. Menurut Badan Pusat Statistik (BPS), kelompok kelas menengah menyumbang setidaknya 45 persen dari total konsumsi domestik (BPS, 2021).

Selain penghasilan yang mengalami kenaikan, kelas menengah juga dicirikan dengan perilaku konsumsinya yang cenderung berorientasi pada pemenuhan kebutuhan sekunder, bahkan tersier. Salah satunya ialah kebutuhan atas kepemilikan kendaraan pribadi, baik sepeda motor atau mobil. Menjadi wajar jika angka penjualan kendaraan bermotor di Indonesia mengalami lonjakan drastis dalam beberapa tahun terakhir. 
Data Asosiasi Industri Sepeda Motor Indonesia (AISI) menyebut, sepanjang 2019 tercatat 1.100.950 unit sepeda motor terjual naik 19,4 persen dari 2018 (922.123 unit). Kenaikan juga terjadi pada penjualan mobil. Data Gabungan Industri Kendaraan Bermotor Indonesia (GAIKINDO) mencatat 851.430 unit mobil terjual pada 2018 naik 10,85 persen dibanding 2017 (786.120 unit). Selain itu, segmen mobil yang diproduksi di Indonesia melalui kebijakan pemerintah "Low Cost Green Car" (LCGC) menyumbang 13,52 persen dari total penjualan (Ramadhi et al., 2021).

Menurut Kementerian Perindustrian (Kemenperin) menyatakan bahwa laju industri otomotif nasional di masa pandemic COVID-19 masih menjanjikan. Hal ini tercermin dari kembali menggeliatnya volume penjualan mobil usai anjlok di kuartal II 2020, pembangunan infrastruktur yang terus dilakukan dan tingginya kapasitas produksi dengan didukung populasi kelas menengah. Lebih jauh, saat ini Indonesia memiliki 22 perusahaan industri KBM (penjualan kendaraan bermotor) roda empat atau lebih yang memiliki fasilitas perakitan dan atau manufaktur di dalam negeri dengan kapasitas produksi sekitar 2,2 juta unit per tahun, seperti yang di sampaikan oleh Direktur Industri Maritim, Alat Transportasi, dan Alat Pertahanan (IMATAP) Kemenperin, Putu Juli Ardika, dalam keterangannya, Selasa (21 Juli 2020).

Penyerapan tenaga kerja secara langsung sebanyak 75 ribu orang serta tenaga kerja tidak langsung sebanyak 1,5 juta orang menyebabkan banyak sektor yang bersinggungan dengan sector otomotif. Di samping itu, saat ini ada sekitar 1.550 perusahaan industri bahan baku dan komponen otomotif dalam negeri, yang terdiri atas 550 perusahaan industri tier 1, dan 1.000 perusahaan industri merupakan tier 2 dan 3. Dari jumlah tersebut, 237 perusahaan industri tergabung dalam GIAMM (Gabungan Industri Alat Mobil dan Motor) dan 128 perusahaan industri tergabung dalam PIKKO (Perkumpulan Industri Kecil dan Menengah Komponen Otomotif). Sementara dari sisi penjualan, menurut data Gabungan Industri Kendaraan Bermotor Indonesisa (Gaikindo), wholesales di Juni 2020 meningkat 255 persen dari 3.551 unit di Mei 2020 menjadi 12.623 unit (Amri \& Ramdani, 2020).

Sementara penjualan retail di periode sama, naik 11 ribuan unit yaitu dari 17.083 unit menjadi 29.862 unit. Namun, secara tahunan, kinerja penjualan mobil di semester I tahun 2020 memang mengalami perlambatan sebesar 46 dibandingkan tahun 2019. Pada tahun 2019 kinerja industri kendaraan roda empat nasional pada dapat meproduksi mobil mencapai 1,28 juta unit kendaraan (setara 13,17 miliar dolar AS) atau turun 4,2 persen dari tahun sebelumnya. Namun demikian, kinerja ekspor kendaraan bermotor tahun 2019 baik dalam bentuk CBU (mobil dalam keadaan utuh) maupun CKD (mobil dirakit di dalam negeri) mengalami peningkatan cukup signifikan dari tahun sebelumnya. Yakni, 25,7 persen untuk CBU dan 523 persen di sisi CKD.

Penjualan kendaraan bermotor (KBM) roda empat atau lebih pada 2019 masih didominasi jenis kendaraan multifungsi (MPV) di bawah $1.500 \mathrm{cc}$ sebanyak 442 ribu unit atau menyumbang sekitar 43 persen dari total penjualan nasional. Adapun jenis kendaraan bermotor roda empat yang hemat energi dan harga terjangkau (KBH2) di bawah $1.200 \mathrm{cc}$ sebanyak 217 ribu unit atau menyumbang sekitar 21 persen dari total penjualan nasional. 


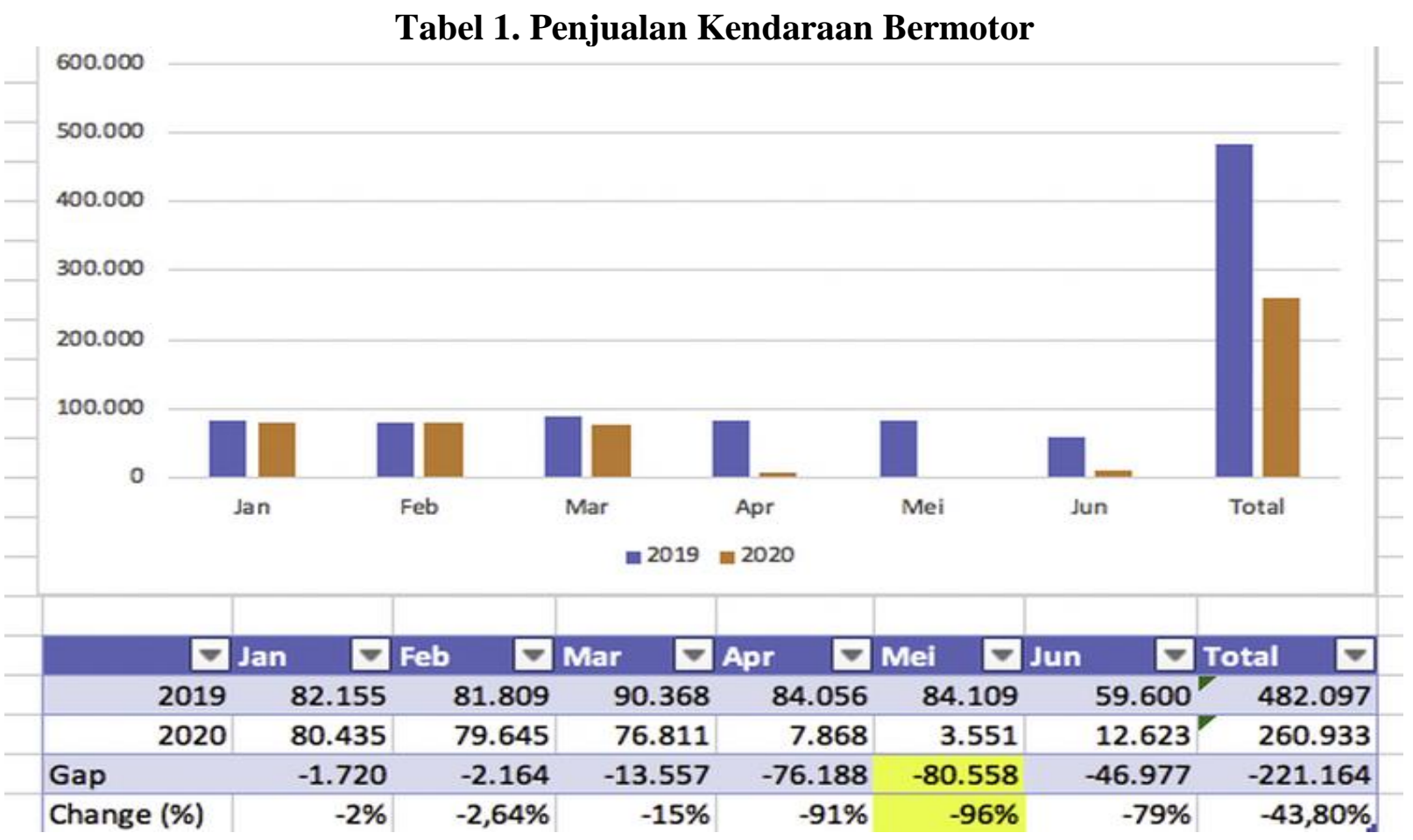

Sumber : www.kompas.com (2021)

Kinerja perusahaan otomotif di dunia pada masa pandemi COVID-19 ini mengalami penurunan yang sangat signifikan. Begitu pula di Indonesia, juga mengalami hal yang sama. Hal ini disebabkan antara lain penurunan permintaan akan kendaraan, adanya wilayah yang menerapkan PSBB (Pembatasan Sosial Berskala Besar). Sejak pemberlakuan PSBB pada Maret 2020, membuat segala jenis kegiatan produksi di perusahaan berhenti sementara, termasuk dengan industri otomotif.

Uraian di atas, maka dapat dikemukakan identifikasi permasalahan dimana volume penjualan perusahaan otomotif selama masa pandemi COVID-19 mengalami penurunan, permintaan akan kebutuhan kendaraan selama masa pandemi COVID-19 mengalami penurunan, kinerja keuangan perusahaan otomotif pengalami penurunan, adanya penurunan daya beli masyarakat terhadap mobil atau kendaraan selama masa pandemi COVID-19, penurunan jumlah produksi perusahaan otomotif selama masa pandemi COVID-19, dan penghentian sementara produksi pada perusahaan otomotif karena adanya PSBB (Pembatasan Sosial Berkala Besar). Sehingga batasan penelitian iniyaitu perusahaan otomotif yang terdaftar pada BEI. Data yang akan digunakan dalam penelitian ini adalah data perusahaan industri otomotif sebelum masa pandemi COVID-19 dan selama pandemi.

Dengan demikian, maka dalam penyusunan artikel ini terdapat lima buah variabel, yang terdiri dari dua buah variabel bebas (independent variables), variabel terikat (dependent variable). Dalam penelitian ini ditetapkan bahwa faktor eksternal dijadikan variabel bebas satu (X1), likuiditas sebagai variabel bebas dua (X2). Sedangkan profitabilitas sebagai variabel dependen (Y) dan harga saham sebagai variabel intervening (Z). Oleh karena itu penelitian ini diberi judul "Pengaruh Pandemi COVID-19 Terhadap Kinerja Perusahaan (Profitabilitas, Likuiditas, Faktor Eksternal, dan Harga Saham) Pada Perusahaan Industri Otomotif di BEI". 
Berdasarkan latar belakang masalah yang telah diuraikan dan identifikasi permasalahan di atas, peneliti menyimpulkan bahwa permasalahan yang akan menjadi rumusan dalam penelitian ini adalah:

1. Apakah faktor eksternal berpengaruh terhadap profitabilitas perusahaan otomotif yang terdaftar di BEI pada tahun 2019 (sebelum pandemi COVID-19) dan tahun 2020 (selama pandemi COVID-19)

2. Apakah Likuiditas berpengaruh terhadap profitabilitas perusahaan otomotif yang terdaftar di BEI pada tahun 2019 (sebelum pandemi COVID-19) dan tahun 2020 (selama pandemi COVID-19)?

3. Apakah profitabilitas berpengaruh terhadap harga saham perusahaan otomotif yang terdaftar di BEI pada tahun 2019 (sebelum pandemi COVID-19) dan tahun 2020 (selama pandemi COVID-19)?

4. Apakah likuiditas berpengaruh terhadap profitabilitas perusahaan otomotif yang terdaftar di BEI pada tahun 2019 (sebelum pandemi COVID-19) dan tahun 2020 (selama pandemi COVID-19)?

5. Apakah likuiditas berpengaruh terhadap harga saham perusahaan otomotif yang terdaftar di BEI pada tahun 2019 (sebelum pandemi COVID-19) dan tahun 2020 (selama pandemi COVID-19)

6. Bagaimana perbandingan ratio kinerja keuangan pada perusahaan otomotif yang terdaftar di BEI pada tahun 2019 (sebelum pandemi COVID-19) dan tahun 2020 (selama pandemi COVID-19)?

\section{Landasan Teori \\ Defenisi Kinerja Keuangan}

Dalam menilai keberhasilan suatu perusahaan dapat di lihat dari kinerja keuangan suatu perusahaan. Kinerja keuangan perusahaan tercermin dalam laporan keuangan perusahaan. Untuk itu investor harus melakukan studi terhadap berbagai hubungan antar pos dalam laporan keuangan sehingga dapat diketahui kondisi keuangan serta perkembangan dan hasil operasi yang telah dicapai perusahaan (Munawir, 2010). Kinerja keuangan adalah suatu analisis yang dilakukan untuk melihat sejauh mana suatu perusahaan telah melaksanakan dengan menggunakan aturan-aturan pelaksanaan keuangan secara baik dan benar. Kinerja perusahaan merupakan suatu gambaran tentang kondisi keuangan suatu perusahaan yang dianalisis dengan alat-alat analisis keuangan, sehingga dapat diketahui mengenai baik buruknya keadaan keuangan suatu perusahaan yang mencerminkan prestasi kerja dalam periode tertentu. Hal ini sangat penting agar sumber daya digunakan secara optimal dalam menghadapi perubahan lingkungan (Fahmi, 2011:2).

\section{Rasio-rasio Keuangan}

Rasio keuangan atau rasio finansial merupakan suatu alat dalam menganalisa dan mengukur kinerja perusahaan dengan menggunakan parameter kondisi atau data keuangan perusahaan tersebut. Data-data keuangan tersebut biasanya diambil dari laporan keuangan yang ada, seperti neraca, laporan laba rugi, laporan arus kas. Rasio keuangan merupakan perbandingan dua data keuangan dengan jalan membagi satu data dengan data lainnya. Analisis rasio keuangan ini adalah dasar untuk menilai dan menganalisis prestasi operasi perusahaan. Di samping itu, analisis rasio keuangan juga dapat dipergunakan sebagai kerangka kerja perencanaan dan pengendalian keuangan (Sartono, 2008). Pada dasarnya analisis rasio keuangan dapat dikelompokkan dalam lima macam kategori, antara lain (Sartono, 2008): 1) Rasio Likuiditas, yaitu rasio yang digunakan untuk mengetahui 
kemampuan perusahaan dalam memenuhi kewajiban jangka pendeknya yang belum jatuh tempo. Misalnya current ratio dan quick ratio. 2) Rasio Aktivitas, yaitu rasio yang digunakan untuk mengukur efektivitas perusahaan dalam menggunakan aktiva. Dapat pula dikatakan rasio ini mengukur tingkat efisiensi (efektivitas) pemanfaatan sumber daya perusahaan. 3) Rasio Hutang, yaitu rasio yang menunjukkan kapasitas perusahaan untuk memenuhi kewajiban baik jangka pendek maupun jangka panjang, misalnya debt equity ratio. 4) Rasio Profitabilitas, yaitu rasio keuangan yang menunjukkan seberapa besar kemampuan perusahaan memperoleh laba, baik dalam hubungannya dengan asset maupun ekuitas. Misalnya, net profit margin, return on assets, return on equity. 5) Rasio Pasar, yaitu rasio yang menghubungkan harga saham perusahaan dengan laba dan nilai buku per saham. Rasio ini memberikan manajemen petunjuk mengenai apa yang dipikirkan oleh investor atas kinerja manajemen masa lalu dan prospek masa mendatang. Misalnya, PER (Price Earningss Ratio) dan PBV (Price to Book Ratio).

\section{Profitabilitas.}

Profitabilitas atau laba adalah pendapatan dikurangi beban dan kerugian selama periode pelaporan. Analisis mengenai profitabilitas sangat penting bagi kreditor dan investor ekuitas. Bagi kreditor, laba merupakan sumber pembayaran bunga dan pokok pinjaman. Sedangkan bagi investor ekuitas, laba merupakan salah satu faktor penentu perubahan nilai efek. Hal yang terpenting bagi perusahaan adalah bagaimana laba tersebut bisa memaksimalkan pemegang saham bukan seberapa besar laba yang dihasilkan oleh perusahaan. Menurut Saidi (2004), profitabilitas adalah kemampuan perusahaan dalam memperoleh laba. Para investor menanamkan saham pada perusahaan adalah untuk mendapatkan return. Semakin tinggi kemampuan perusahaan memperoleh laba, maka semakin besar return yang diharapkan investor, sehingga menjadikan nilai perusahaan menjadi lebih baik.

\section{Likuiditas.}

Melalui sumber informasi tentang modal kerja yaitu pos-pos aktiva lancer dan hutang lancar. Current Ratio merupakan salah satu rasio likuiditas. Current Ratio menunjukan tingkat tingkat keamanan (margin of safety) kreditor jangka pendek. Tetapi current ratio yang tinggi belum tentu menjamin akan dapat dibayarnya hutang perusahaan yang sudah jatuh tempo karena proporsi atau distribusi dari aktiva lancar yang tidak menguntungakan (Munawir, 2004). Rasio ini dapat dibuat dalam bentuk berapa kali atau dalam bentuk persentase. Apabila rasio lancar ini 1:1 atau 100\%, ini berarti bahwa aktiva lancar dapat menutupi semua hutang lancar. Rasio lancar yang lebih aman adalah jika berada di atas 1 atau di atas 100\% (Harahap, 1998;301).

\section{Harga Saham.}

Harga saham merupakan tanda penyertaan atau kepemilikan seseorang atau badan dalam suatu perusahaan, yang merupakan refleksi dari keputusan investasi, pendanaan, dan pengelolaan aset. Harga saham sangat ditentukan dari penawaran dan permintaan akan saham itu sendiri. Semakin banyak orang yang membeli saham maka harga saham cenderung bergerak naik dan sebaliknya semakin banyak orang yang menjual sahamnya maka harga saham cenderung bergerak turun (Rahmadewi \& Abundanti, 2018). Harga saham menjadi penting karena terkait dengan capital gain besar seperti yang diinginkan oleh semua investor. Jika harga saham meningkat setelah suatu saham dibeli, maka dapat kita simpulkan, kinerja saham emiten tersebut bagus, begitu juga sebaliknya. Jika harga saham setelah dibeli mengalami penurunan dari harga awal, maka investor akan mengalami capital loss. Menurut Jogiyanto harga saham adalah harga yang terjadi di pasar bursa pada saat tertentu yang ditentukan oleh pelaku pasar dan ditentukan oleh permintaan dan penawaran saham yang bersangkutan di pasar modal. Menurut Suad Husnan dan Enny 
Pudjiastuti harga saham merupakan nilai sekarang (present value) dari penghasilanpenghasilan yang akan diterima oleh pemodal dimasa yang akan datang. Dapat disimpulkan harga saham adalah harga selembar saham yang terjadi pada saat tertentu yang ditentukan oleh permintaan dan penawaran di pasar modal. Sedangkan menurut Perdana dan Kristanti, Harga saham merupakan salah satu indikator pengelolaan perusahaan. Keberhasilan dalam menghasilkan keuntungan akan memberikan kepuasan bagi investor yang rasional.

Inflasi.

Inflasi adalah proses kenaikan harga-harga umum barang-barang secara terus menerus. Ini tidak berarti bahwa harga-harga berbagai macam barang itu naik dengan presentase yang sama. Mungkin dapat terjadi kenaikan tersebut tidaklah bersamaan. Yang penting terdapat kenaikan harga umum barang secara terus menerus selama satu periode tertentu. Kenaikan yang terjadi hanya sekali saja (meskipun dengan presentase yang cukup besar) bukanlah merupakan inflasi. Kenaikan harga diukur dengan menggunakan index harga. Ada tiga macam indeks harga yang digunakan untuk menghitung laju inflasi, yaitu Indeks Harga Konsumen (IHK), Indeks Harga Produsen (IHP) dan Indeks Harga Perdagangan Besar (IHPB).

\section{Kerangka Pemikiran.}

\section{Pengaruh faktor eksternal terhadap profitabilitas}

Faktor eksternal dan faktor internal berpengaruh terhadap kinerja suatu perusahaan dalam mendapatkan profitabilitas. Profitabilitas dalam kondisi makro ekonomi biasa akan sensitif terhadap faktor eksternal terutama inflasi. Inflasi yang tinggi akan menekan terhadap suku bunga sehingga menyebabkan profitabilitas suatu perusahaan mengalami perubahan. Berdasarkan penelitian Dedi Supriadi dan Budi S. Purnomo (2019) menyatakan bahwa inflasi (faktor eksternal) berpengaruh negatif terhadap profitabilitas bank syariah di Indonesia.

\section{Pengaruh likuiditas terhadap profitabilitas.}

Likuiditas merupakan gambaran kemampuan perusahaan dalam mengembalikan hutang jangka pendek. Semakin tinggi tingkat likuiditas perusahaan maka semakin baik posisi perusahaan dimata kreditur karena perusahaan dianggap dapat membayar kewajibannya kepada kreditur pada tepat waktu, tetapi hal ini mengakibatkan dana atau keuangan yang menganggur sehingga tidak memaksimalkan pinjaman dana yang diperoleh untuk meningkatkan keuntungan dari sebelumnya. Menurut Lubis, Sinaga dan Sasongko (2017), Zuhroh (2019) dalam penelitiannya menyatakan bahwa likuiditas berpengaruh signifikan terhadap profitabilitas. Jadi dengan melihat rasio likuiditas suatu perusahaan maka pihak kreditur dapat menilai baik buruknya perusahaan tersebut. Teori yang di kemukakan oleh Brigham dan Houston (2006) menjelaskan bahwa harga saham kemungkinan akan tinggi sesuai yang di perkirakan jika nilai dari rasio likuiditas, manajemen aset, manajemen utang dan rasio profitabilitas terlihat baik dan kondisi tersebut berjalan terus secara stabil. Jika Current rasio baik maka kemampuan perusahaan akan semakin baik dalam mencukupi hutang jangka pendek dan terhindar dari masalah likuiditas. Hal itulah yang akhirnya membuat investor tertarik dan berakibat pada naiknya harga saham. Hasil penelitian Setiawan dan Pardiman (2014) menunjukkan bahwa current rasio berpengaruh positif dan signifikan terhadap harga saham.

\section{Pengaruh profitabilitas terhadap harga saham.}

Harga saham adalah harga di pasar bursa pada saat tertentu yang di tentukan oleh pelaku pasar. Jika harga saham suatu perusahaan tinggi, maka hal ini mencerminkan nilai perusahaan dan efektivitas perusahaan baik. Bagi investor informasi tentang rasio 
profitabilitas menjadi kebutuhan yang sangat mendasar dalam pengambilan keputusan dalam berinvestasi. Perkembangan harga saham tidak terlepas dari perkembangan kinerja keuangan yang di tunjukkan dengan kenaikan profitabilitas.Secara umum jika kinerja keungan mengalami kenaikan maka harga saham juga akan mengalami kenaikan. Hal ini di dukung penelitian oleh Ade Wulandari dan Ida Bagus Braja (2019) yang menyatakan bahwa ROE (return on equity) dan NPM (net profit margin) yang merpakan rasio profitablitas berpengaruh positif terhadap harga saham pada perusahaan LQ-45.

\section{Pengaruh faktor eksternal terhadap harga saham.}

Faktor eksternal dalam hal ini kurs, inflasi dan suku bunga mempunyai pengaruh terhadap profitabilitas.Harga saham di pengaruhi oleh faktor internal dan faktor eksternal yang membuat harga saham berfluktuasi. Dalam penelitian ini faktor eksternal yang akan di jadikan obyek penelitian adalah inflasi dan suku bunga. Berdasar penelitian Andrew Patar, Darminto, dan M.Saifi (2014) yang menyatakan bahwa faktor eksternal (kurs,inflasi,dan suku bunga) secara simultan berpengaruh terhadap harga saham.

5. Pengaruh likuiditas terhadap harga saham.

Teori yang di kemukakan oleh Brigham dan Houston (2006) menjelaskan bahwa harga saham kemungkinan akan tinggi sesuai yang di perkirakan jika nilai dari rasio likuiditas,manajemen aset, manajemen utang dan rasio profitabilitas terlihat baik dan kondisi tersebut berjalan terus secara stabil. Jika Current rasio baik maka kemampuan perusahaan akan semakin baik dalam mencukupi hutang jangka pendek dan terhindar dari masalah likuiditas.Hal itulah yang akhirnya membuat investor tertarik dan berakibat pada naiknya harga saham. Hasil penelitian Setiawan dan Pardiman (2014) menunjukkan bahwa current rasio berpengaruh positif dan signifikan terhadap harga saham.

Berdasarkan pembahasan di atas, maka pada penelitian ini terdapat empat variabel yang terdiri dari dua buah variabel bebas (independent variables), satu variabel terikat (dependent variabel) dan satu variabel intervening. Dalam penelitian ini ditetapkan bahwa Faktor Eksternal dijadikan variabel bebas satu (X1), Likuiditas sebagai variabel bebas dua (X2), Profitabilitas sebagai variabel terikat (Y), Sedangkan Harga saham sebagai variabel intervening (Z). Sebagai fokus penelitian ini adalah Perusahaan Otomotif yang terdaftar di BEI. Dengan demikian bentuk kerangka konseptual penelitian ini sebagai berikut: 


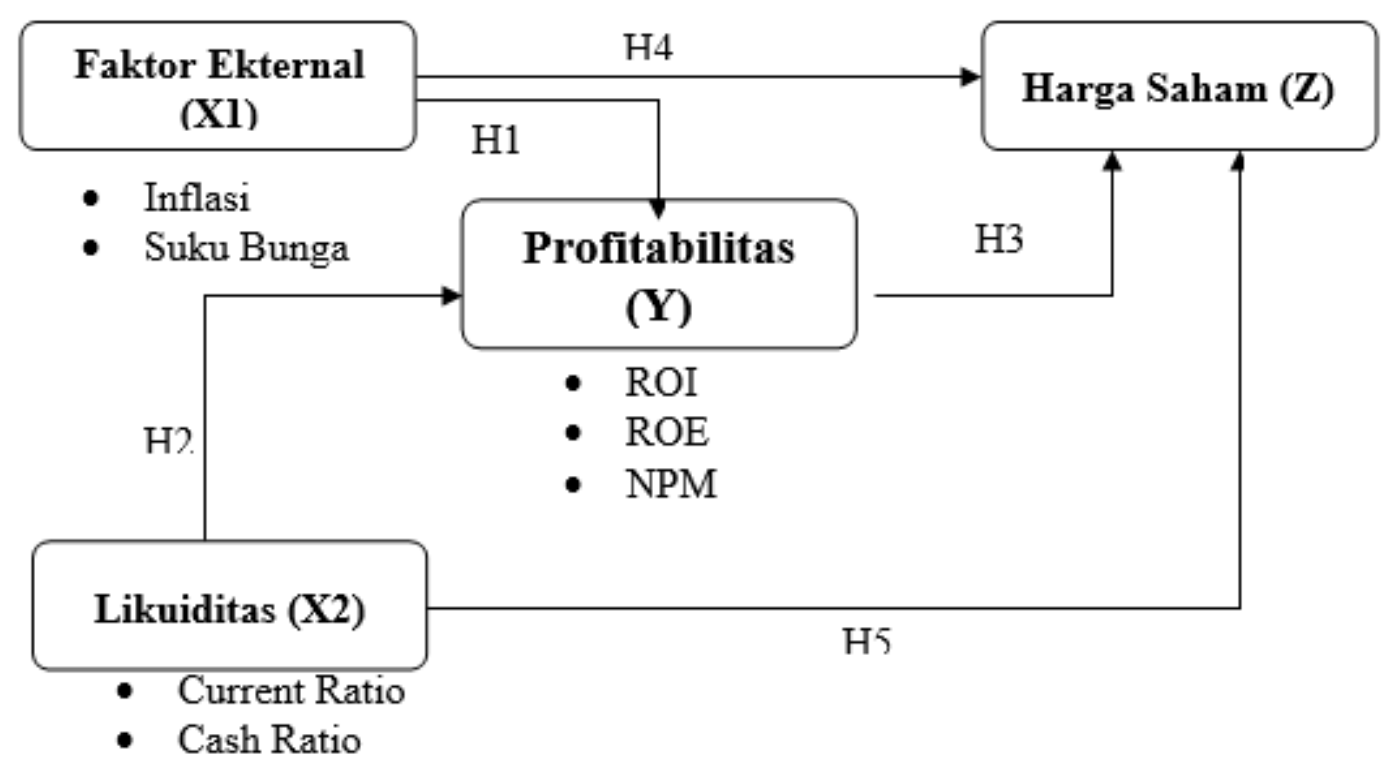

\section{Hipotesis Penelitian.}

Gambar 1. Kerangka Pemikiran

Hipotesis merupakan kesimpulan atau dugaan sementara atas suatu persyaratan yang kebenarannya harus diuji apakah pernyataan tersebut benar atau salah. Dalam penelitian ini dikemukakan hipotesis sebagai berikut :

H1 : Faktor eksternal berpengaruh terhadap profitabilitas

H2 : Likuiditas berpengaruh terhadap profitabilitas

H3 : Profitabilitas berpengaruh terhadap harga saham

H4 : Faktor eksternal berpengaruh terhadap harga saham

H5 : Likuiditas berpengaruh terhadap harga saham

\section{Metode Penelitian.}

Metode yang digunakan dalam penelitian ini adalah metode kuantitatif. Metode penelitian kuantitatif dapat diartikan sebagai metode yang di gunakan untuk meneliti pada populasi atau sampel tertentu, pengumpulan data menggunakan instrument penelitian, analisis bersifat statistik dengan tujuan untuk menguji hipotesa yang sudah di tetapkan. Data yang akan di pakai dalam penelitian ini adalah data sekunder yaitu data yang bersumber Bursa Efek Indonesia (BEI) terkait laporan keuangan perusahaan otomotif yang terdaftar di Bursa Efek Indonesia (BEI) melalui website www.idx.co.id mulai tahun 2019 dan 2020. Populasi dalam penelitian ini adalah seluruh perusahaan yang otomotif terdaftar di Bursa Efek Indonesia (BEI). Sampel dalam penelitian ini adalah semua perusahaan otomotif yang listing di Bursa Efek Indonesia. Berdasarkan survei awal yang dilakukan, ada 5 perusahaan otomotif yang listing di BEI, yaitu: PT Astra International Tbk., PT Mitra Pinasthika Mustika Tbk., PT Indomobil Sukses Indonesia Tbk., PT Gajah Tunggal Tbk., PT Goodyear Indonesia Tbk.

Data yang akan di gunakan dalam penelitian ini adalah data sekunder yaitu data yang bersumber Bursa Efek Indonesia (BEI) terkait laporan keuangan perusahaan otomotif yang akan di jadikan sampel penelitian yaitu laporan keuangan perusahaan otomotif triwulan tahun 2019 sebelum pandemi COVID-19 dan tahun 2020 setelah pandemi COVID-19. Dalam penelitian ini terdapat dua variabel penelitian, yaitu variabel 
independen adalah faktor eksternal (X1), likuiditas (X2) dan variabel dependen adalah Profitabilitas (Y). Teknik analisis data menggunakan uji SEM PLS.

\section{Definisi Operasional Variabel dan Dimensi}

Operasional Variabel di sajikan pada tabel berikut:

Tabel 2. Operasionalisasi Variabel: Definisi Operasional, Indikator, dan Skala Ukur

\begin{tabular}{|c|c|c|c|c|c|c|}
\hline No & Variabel & Sub Variabel & Indikator & Keterangan & Skala Ukur & Literatur \\
\hline \multirow{2}{*}{1} & \multirow{2}{*}{ Faktor External } & Inflasi & $\begin{array}{l}\text { Tingkat } \\
\text { Inflasi }\end{array}$ & Rata-rata inflasi setahun & Ratio & Bank Indonesia \\
\hline & & Suku Bunga & $\begin{array}{l}\text { Tingkat } \\
\text { Bunga }\end{array}$ & Rata-rata suku bunga setahun & Ratio & Boediono 2014 \\
\hline \multirow{3}{*}{2} & \multirow{3}{*}{ Likuiditas } & & Proksi & Current Asset & \multirow[b]{2}{*}{ Ratio } & \multirow[b]{2}{*}{ Admaja,2008 } \\
\hline & & Current Ratio & $\begin{array}{l}\text { Current } \\
\text { Rasio }\end{array}$ & $\overline{\text { Current Liabilitis }}$ & & \\
\hline & & Cash Ratio & $\begin{array}{c}\text { Proksi Cash } \\
\text { Ratio }\end{array}$ & $\frac{\text { Cash +Sekuritas }}{\text { Current Liabilitas }}$ & Ratio & Admaja,2008 \\
\hline 3 & Harga Saham & Harga Saham & $\begin{array}{l}\text { Harga } \\
\text { Saham }\end{array}$ & $\begin{array}{c}\text { Hs=Logaritma (Ln),closing } \\
\text { price,Harga Saham }\end{array}$ & kali & $\begin{array}{c}\text { Ginting \& } \\
\text { Suriany,2013 }\end{array}$ \\
\hline \multirow{7}{*}{4} & \multirow{7}{*}{ Profitabilitas } & ROI & Proksi ROI & $\underline{\text { Laba bersih setelah pajak }}$ & Ratio & Kasmir (2015) \\
\hline & & & & Total Aktiva & & \\
\hline & & & & Laba bersih setelah pajak & & \\
\hline & & ROE & Proksi ROE & - & Ratio & Kasmir (2015) \\
\hline & & & & Total Ekuitas & & \\
\hline & & Net Profit & \multirow{2}{*}{ Proksi NPM } & Laba setelah pajak & \multirow{2}{*}{ Ratio } & \multirow{2}{*}{ Kasmir (2015) } \\
\hline & & Margin & & Penjualan & & \\
\hline
\end{tabular}




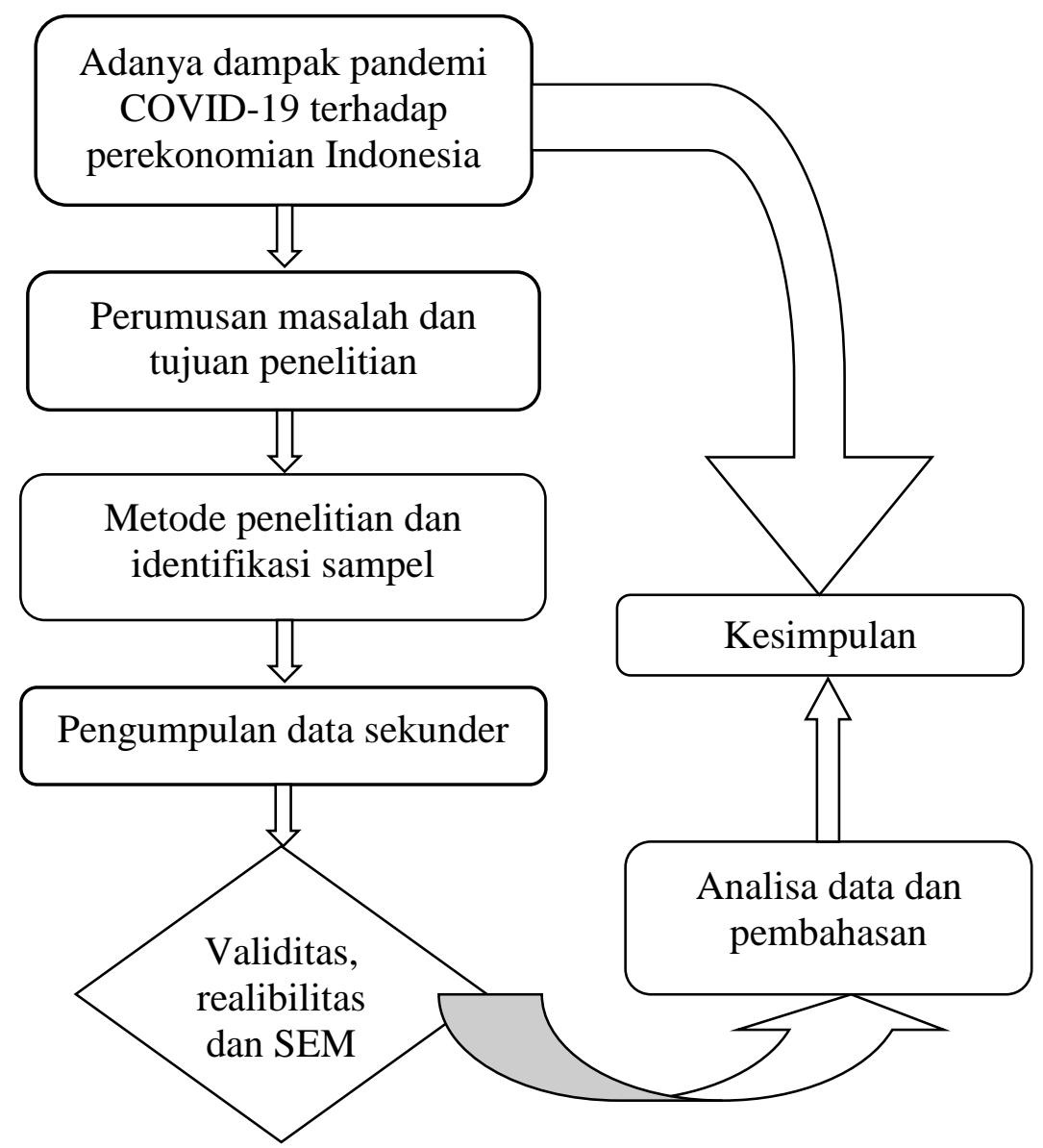

Gambar 2. Alur Penelitian

\section{Hasil dan Pembahasan}

\section{Hasil Uji Data Menggunakan SEM PLS}

Analisis data penelitian menggunakan SEM PLS dimana estimasi data di lakukan secara simultan. Model dalam SEM terdiri dari model pengukuran dan model struktural. Model pengukuran menggambarkan kausalitas antara variabel dengan item pengukuran sedangkan model struktural menggambarkan pengaruh antara variabel penelitian.

\section{Evaluasi Model Pengukuran (Outer Loading)}

Evaluasi terdiri dari loading faktor di atas 0,60, composite Reliability di atas 0,70 dan Average Variance Extracted di atas 0,50.

Tabel 3. Outer Loading

Outer Loadings

\begin{tabular}{|l|l|l|l|l|}
\hline & $\begin{array}{l}\text { Faktor } \\
\text { Eksternal } \\
(\mathrm{X} 1)\end{array}$ & $\begin{array}{l}\text { Harga } \\
\text { Saham } \\
(\mathrm{Z})\end{array}$ & $\begin{array}{l}\text { Likuiditas } \\
(\mathrm{X} 2)\end{array}$ & $\begin{array}{l}\text { Profitabilitas } \\
(\mathrm{Y})\end{array}$ \\
\hline Bunga & $\mathbf{0 . 8 4 9}$ & & & \\
\hline CR & & & $\mathbf{0 . 9 6 5}$ & \\
\hline Cash_Rasio & & & $\mathbf{0 . 8 8 4}$ & \\
\hline HS & & $\mathbf{1 . 0 0 0}$ & & \\
\hline Inflasi & $\mathbf{0 . 9 0 7}$ & & & \\
\hline
\end{tabular}




\begin{tabular}{|l|l|l|l|l|} 
NPM & & & & 0.368 \\
\hline ROE & & & & 0.974 \\
\hline ROI & & & & 0.969 \\
\hline
\end{tabular}

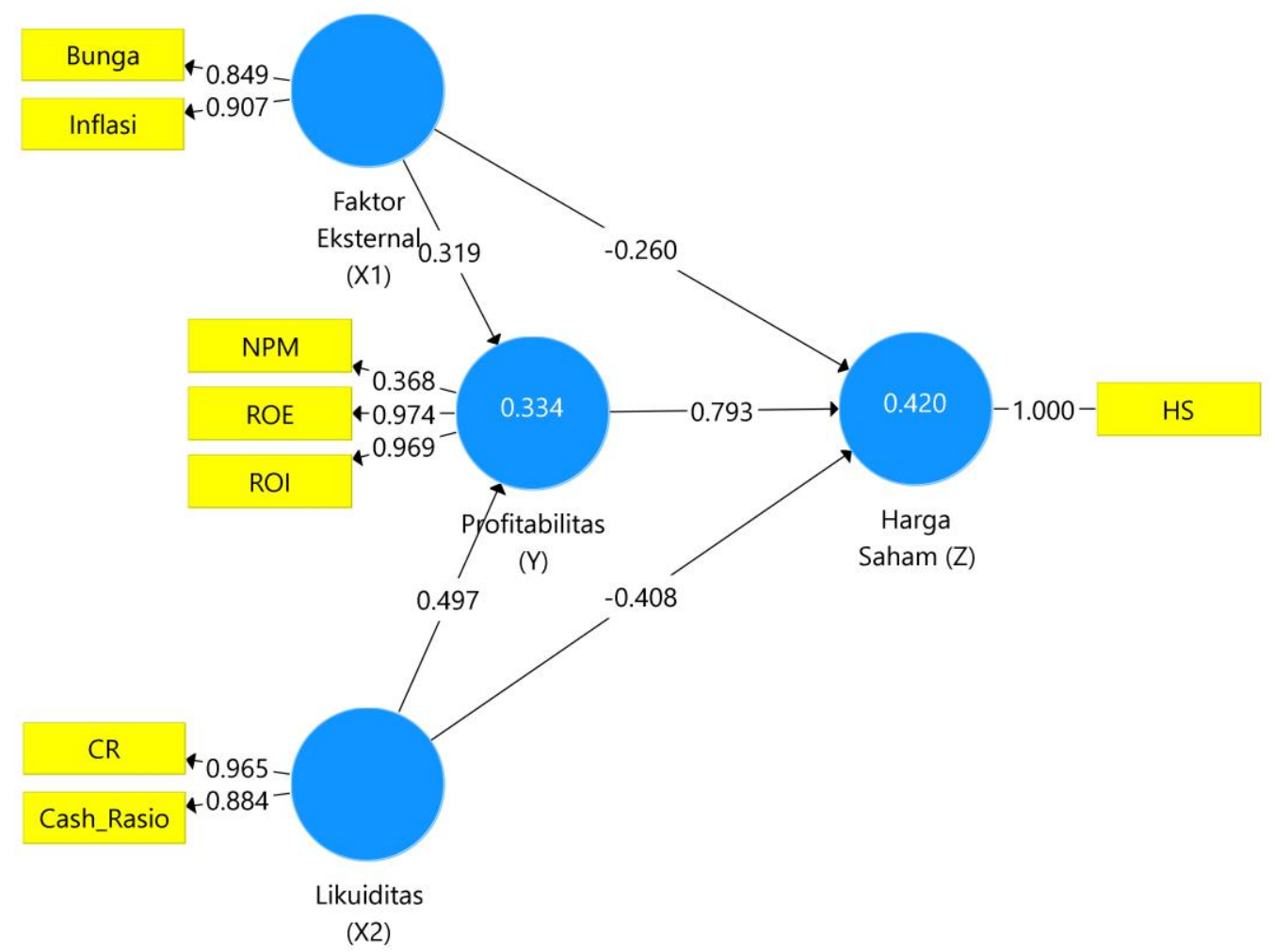

Gambar 2. Hasil Pengolahan SEM

Hasil evaluasi model pengukuran :

1. Indikator faktor eksternal bunga dan inflasi mempunyai outer loading $>0,60$ menunjukkan indikator tersebut sangat kuat menjelaskan kondisi faktor eksternal;

2. $R O E, R O I$ mempunyai nilai outer loading $>0,60$ kuat menjelaskan profitabilitas, untuk NPM memiliki loading factor kurang dari 0,60 yaitu 0,368, hal ini menunjukkan $N P M$ kurang valid dalam mengukur variabel profitabilitas, oleh karena itu maka indikator ini di hapus atau di hilangkan dalam model dan di lakukan estimasi ulang;

3. Current rasio dan cash rasio mempunyai outer loading $>0,60$ sehingga dapat digunakan untuk menjelaskan tentang likuiditas;

4. Harga saham mempunyai outer loading $>0,60$, kuat menjelaskan tentang harga saham.

Pada estimasi tahap kedua, di peroleh nilai outer loading sebagai berikut: 


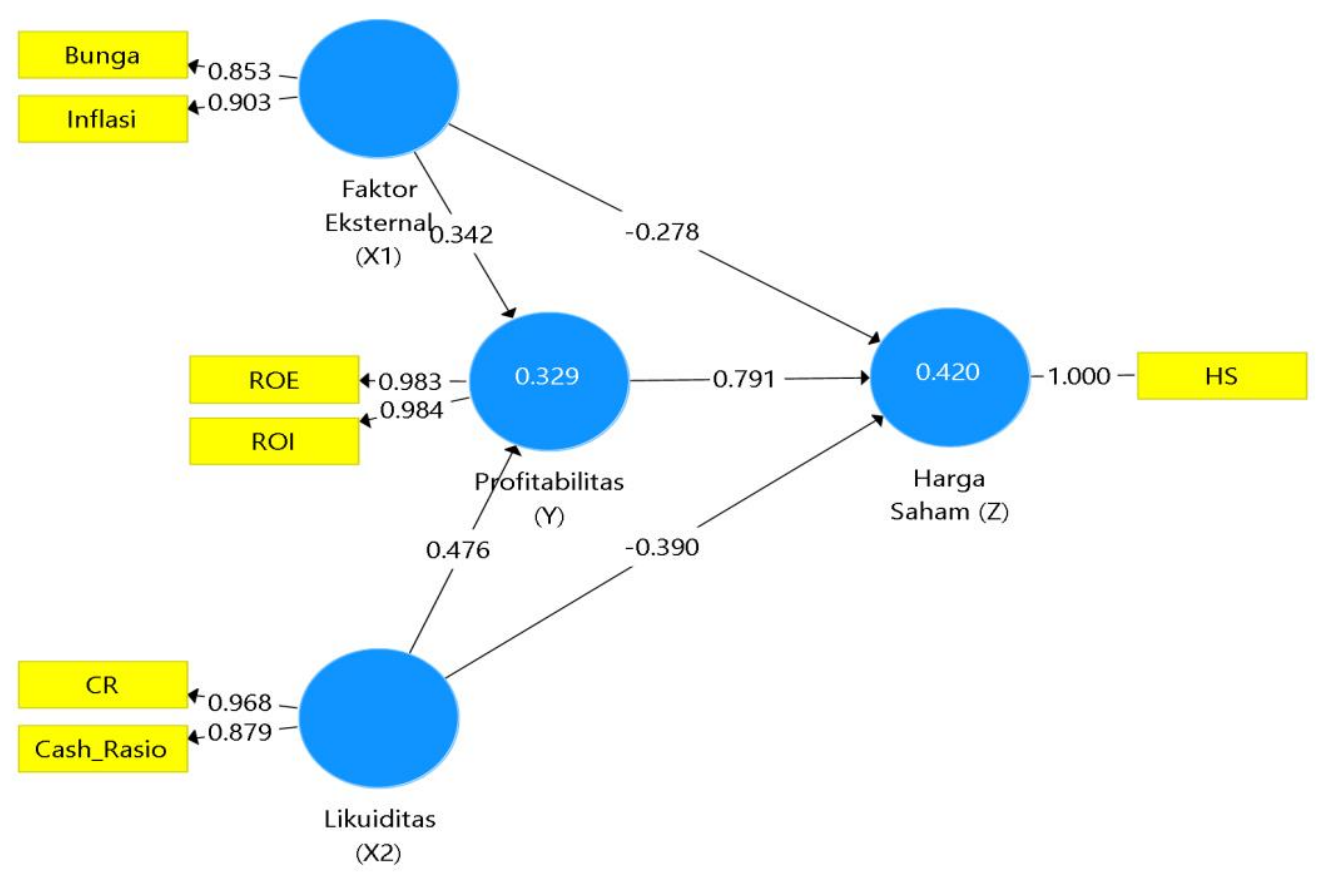

Tabel 4. Outer Loading 2

Outer Loadings

\begin{tabular}{|l|c|c|l|l|}
\hline & $\begin{array}{c}\text { Faktor } \\
\text { Eksternal } \\
(\mathrm{X1})\end{array}$ & $\begin{array}{c}\text { Harga } \\
\text { Saham } \\
(\mathrm{Z})\end{array}$ & $\begin{array}{c}\text { Likuiditas } \\
(\mathrm{X} 2)\end{array}$ & $\begin{array}{c}\text { Profitabilitas } \\
(\text { Y })\end{array}$ \\
\hline Bunga & $\mathbf{0 . 8 5 3}$ & & & \\
\hline CR & & & 0.968 & \\
\hline Cash_Rasio & & & 0.879 & \\
\hline HS & & 1.000 & & \\
\hline Inflasi & 0.903 & & & \\
\hline ROE & & & & 0.983 \\
\hline ROI & & & & 0.984 \\
\hline
\end{tabular}

Setelah indikator yang tidak valid di hapus yaitu NPM (net profit margin) dan di lakukan estimasi ulang (estimasi kedua) terlihat tabel outer loading faktor pada diagram dan tabel di atas semua indikator valid. Loading semua indikator di atas 0,60 (valid) yang berarti bahwa semua indikator valid mencerminkan pengukuran konstruknya. Selanjutnya evaluasi model pengukuran atas convergent validity berikutnya adalah composite Reability, alpha cronbach dan Average variance extracted (AVE ).

Tabel 5. Composite Reliability dan Average Variance Extracted (AVE) Construct Reliability and Validity

\begin{tabular}{|l|l|l|l|l|}
\hline & $\begin{array}{l}\text { Cronbach's } \\
\text { Alpha }\end{array}$ & rho_A & $\begin{array}{l}\text { Composite } \\
\text { Reliability }\end{array}$ & $\begin{array}{l}\text { Average } \\
\text { Variance } \\
\text { Extracted } \\
\text { (AVE) }\end{array}$ \\
\hline $\begin{array}{l}\text { Faktor } \\
\text { Eksternal } \\
(\mathrm{X} 1)\end{array}$ & 0.707 & 0.725 & 0.871 & 0.772 \\
\hline Harga & 1.000 & 1.000 & 1.000 & 1.000 \\
\hline
\end{tabular}




\begin{tabular}{|l|l|l|l|l|} 
Saham (Z) & & & & \\
\hline $\begin{array}{l}\text { Likuiditas } \\
(\mathrm{X} 2)\end{array}$ & 0.844 & 1.104 & 0.921 & 0.854 \\
\hline $\begin{array}{l}\text { Profitabilitas } \\
(\mathrm{Y})\end{array}$ & 0.966 & 0.967 & 0.983 & 0.967 \\
\hline
\end{tabular}

Hasil evaluasi model pengukuran :

1. Semua nilai Cronbach's Alpha masing-masing konstruk $>0,70$ menunjukkan bahwa mempunyai nilai reliabilitas tinggi;

2. Semua Composite Reliability masing-masing konstruk di atas 0,70 menunjukkan indikator yang mengukur variabel konsisten atau dapat di andalkan dalam mengukur variabel;

3. Nilai AVE semua variabel di atas 0,50 menunjukan bahwa variabel mempunyai nilai di atas $50 \%$ variasi indikator. Hal ini menunjukan convergent validity terpenuhi.

\section{Evaluasi Model Struktural}

Evaluasi model pengukuran di lihat dari pengujian signifikansi koefisien jalur atau path coefficients.

\section{Tabel 6. Pengujian Hipotesa}

\begin{tabular}{|l|l|l|l|l|l|}
\hline & $\begin{array}{l}\text { Original } \\
\text { Sample } \\
(\mathbf{O})\end{array}$ & $\begin{array}{l}\text { Sample } \\
\text { Mean } \\
(\mathbf{M})\end{array}$ & $\begin{array}{l}\text { Standard } \\
\text { Deviation } \\
\text { (STDEV) }\end{array}$ & $\begin{array}{l}\text { T Statistics } \\
(\mid \text { O/STDEV|) }\end{array}$ & P Values \\
\hline $\begin{array}{l}\text { Faktor Eksternal (X1) } \\
\text {-> Harga Saham (Z) }\end{array}$ & -0.278 & -0.262 & 0.153 & 1.822 & $\mathbf{0 . 0 6 9}$ \\
\hline $\begin{array}{l}\text { Faktor Eksternal (X1) } \\
\text {-> Profitabilitas (Y) }\end{array}$ & 0.342 & 0.350 & 0.126 & 2.717 & $\mathbf{0 . 0 0 7}$ \\
\hline $\begin{array}{l}\text { Likuiditas (X2) -> } \\
\text { Harga Saham (Z) }\end{array}$ & -0.390 & -0.390 & 0.118 & 3.310 & $\mathbf{0 . 0 0 1}$ \\
\hline $\begin{array}{l}\text { Likuiditas (X2) -> } \\
\text { Profitabilitas (Y) }\end{array}$ & 0.476 & 0.474 & 0.093 & 5.128 & $\mathbf{0 . 0 0 0}$ \\
\hline $\begin{array}{l}\text { Profitabilitas (Y) -> } \\
\text { Harga Saham (Z) }\end{array}$ & 0.791 & 0.791 & 0.134 & 5.894 & $\mathbf{0 . 0 0 0}$ \\
\hline
\end{tabular}

Berdasarkan tabel dan diagram di atas maka pengujian terhadap hipotesa sebagai berikut : Uji t di maksudkan untuk menguji apakah variabel independen secara parsial berpengaruh signifikan terhadap variabel dependen. Dasar pengambilan keputusan adalah : Jika probabilitasnya (nilai prob) $>0.05$ atau $-\mathrm{t}$ tabel $<\mathrm{t}$ hitung $<\mathrm{t}$ tabel maka H0 tidak ditolak; Jika probabilitasnya (nilai prob) $<0.05$ atau t hitung $<-\mathrm{t}$ tabel atau $\mathrm{t}$ hitung $>\mathrm{t}$ tabel maka H0 ditolak ( $\mathrm{t}$ tabel untuk alfa $=0.05$ adalah 1.96 dan $\mathrm{t}$ tabel untuk alfa $=0.10$ adalah 1.65)

Dasar pengujian terhadap hipotesa

1. Faktor eksternal (X1) berpengaruh positif dan signifikan tehadap profitabilitas (Y), dengan koefisien jalur 0,342 dan nilai t hitung $=2,727>1.96$, dan probabilitas $=$ $0,007<0,05$, hal ini dapat di katakan setiap perubahan pada faktor eksternal akan berpengaruh terhadap profitabilitas.

2. Likuiditas (X2) berpengaruh positif dan signifikan terhadap profitabilitas (Y), dengan nilai koefisien jalur 0,476 , memiliki nilai t hitung $=5,128>1.96$ dan probabilitas 
$0,000<0,05$. Setiap adanya perubahan tingkat likuiditas akan berpengaruh terhadap profitabilitas.

3. Profitabilitas ( $\mathrm{Y}$ ) berpengaruh positif dan signifikan terhadap harga saham ( $\mathrm{Z}$ ), dengan nilai koefisien jalur 0,791, memiliki nilai t hitung 5,894>1,96 dan probabilitas $0,000<0,05$. Setiap adanya peningkatan profitabilitas akan berpengaruh terhadap peningkatan harga saham.

4. Faktor eksternal ( X1 ) berpengaruh negatif dan tidak signifikan terhadap harga saham ( $\mathrm{Z}$ ) karena memiliki koefisien jalur -0,278 dan tidak signifikan karena memiliki nilai t hitung 1,822 < 1,96 dan probabilitas $0,069>0,05$. Perubahan pada faktor eksternal tidak secara langsung berpengaruh terhadap harga saham.

5. Likuiditas (X2 ) berpengaruh negatif signifikan terhadap harga saham ( Z), karena memiliki nilai koefisien jalur $=-0,390$, sedang nilai t hitung $=3.310>1.96$, dan probabilitas $0,001<0,05$, sehingga setiap perubahan pada likuiditas akan berpengaruh terhadap harga saham.

Tabel 7. Tabel R Square

\begin{tabular}{|l|l|l|}
\hline & $\begin{array}{l}\text { R } \\
\text { Square }\end{array}$ & $\begin{array}{l}\text { R Adjusted } \\
\text { Hquare }\end{array}$ \\
\hline $\begin{array}{l}\text { Harga Saham } \\
\text { (Z) }\end{array}$ & 0.420 & 0.372 \\
\hline $\begin{array}{l}\text { Profitabilitas } \\
\text { (Y) }\end{array}$ & 0.329 & 0.293 \\
\hline
\end{tabular}

$\mathrm{R}$ square menggambarkan pengaruh bersama (dalam persen) antara sejumlah variabel. Hasil R square diatas dapat diketahui ;

1. Pengaruh bersama faktor eksternal ,likuiditas, dan profitabilitas terhadap harga saham sebesar $37,2 \%$ dan sisanya $62,8 \%$ di pengaruhi oleh variabel lainnya yang tidak masuk dalam model.

2. Pengaruh bersama faktor eksternal dan likuiditas terhadap profitabilitas sebesar 32,9 $\%$ dan sisanya $67,1 \%$ di pengaruh oleh variabel lainnya yang tidak masuk dalam model.

Tabel 8. Path Koefisien

\begin{tabular}{|l|l|l|l|l|}
\hline & $\begin{array}{l}\text { Faktor } \\
\text { Eksternal } \\
\text { (X1) }\end{array}$ & $\begin{array}{l}\text { Harga } \\
\text { Saham } \\
\text { (Z) }\end{array}$ & $\begin{array}{l}\text { Likuiditas } \\
\text { (X2) }\end{array}$ & $\begin{array}{l}\text { Profitabilitas } \\
\text { (Y) }\end{array}$ \\
\hline $\begin{array}{l}\text { Faktor Eksternal } \\
\text { (X1) }\end{array}$ & & -0.278 & & 0.342 \\
\hline Harga Saham (Z) & & & & \\
\hline Likuiditas (X2) & & -0.390 & & 0.476 \\
\hline Profitabilitas (Y) & & 0.791 & & \\
\hline
\end{tabular}

Path koefisien menggambarkan besar dan arah pengaruh antara variabel dimana :

1. Faktor eksternal (X1) mempunyai pengaruh negatif sebesar $-0,278$ terhadap harga saham dan mempunyai pengaruh positif sebesar 0,342 terhadap profitabilitas.

2. Likuiditas ( X2 ) mempunyai pengaruh negatif sebesar -0.390 terhadap harga saham ( Z) dan mempunyai pengaruh positif sebesar 0.476 terhadap profitabilitas ( Y).

3. Profitabilitas (Y) mempunyai pengaruh positif sebesar 0,791 terhadap harga saham ( Z) 
Tabel 9.Tabel Indirect Effects

\begin{tabular}{|l|l|l|l|l|}
\hline & $\begin{array}{l}\text { Faktor } \\
\text { Eksternal } \\
\text { (X1) }\end{array}$ & $\begin{array}{l}\text { Harga } \\
\text { Saham } \\
\text { (Z) }\end{array}$ & $\begin{array}{l}\text { Likuiditas } \\
\text { (X2) }\end{array}$ & $\begin{array}{l}\text { Profitabilitas } \\
\text { (Y) }\end{array}$ \\
\hline $\begin{array}{l}\text { Faktor Eksternal } \\
\text { (X1) }\end{array}$ & 0.271 & & \\
\hline Harga Saham (Z) & & & & \\
\hline Likuiditas (X2) & & 0.377 & & \\
\hline Profitabilitas (Y) & & & & \\
\hline
\end{tabular}

Tabel 10. Specific Indirect Effects

\begin{tabular}{|l|l|}
\hline & $\begin{array}{l}\text { Specific } \\
\text { Indirect } \\
\text { Effects }\end{array}$ \\
\hline $\begin{array}{l}\text { Faktor Eksternal } \\
\text { (X1) -> }\end{array}$ & \\
Profitabilitas (Y) & 0.271 \\
-> Harga Saham & \\
(Z) & \\
\hline $\begin{array}{l}\text { Likuiditas (X2) }-> \\
\text { Profitabilitas (Y) }\end{array}$ & 0.377 \\
-> Harga Saham & \\
(Z) & \\
\hline
\end{tabular}

Tabel indirect effect diatas artinya adalah pengaruh tidak langsung, dari tabel tersebut di atas dapat di ketahui :

1. Besar pengaruh tidak langsung faktor eksternal ( $X 1$ ) terhadap harga saham ( $Z$ ) melalui profitabilitas ( Y) sebesar 0,271

2. Besar pengaruh tidak langsung likuiditas ( X2 ) terhadap harga saham ( Z) melalui profitabilitas sebesar 0,377.

Tabel 11.Total Effects

\begin{tabular}{|l|l|l|l|l|}
\hline & $\begin{array}{l}\text { Faktor } \\
\text { Eksternal } \\
(\mathbf{X 1})\end{array}$ & $\begin{array}{l}\text { Harga } \\
\text { Saham } \\
(\mathbf{Z})\end{array}$ & $\begin{array}{l}\text { Likuiditas } \\
\text { (X2) }\end{array}$ & $\begin{array}{l}\text { Profitabilitas } \\
\text { (Y) }\end{array}$ \\
\hline $\begin{array}{l}\text { Faktor Eksternal } \\
(\text { X1) }\end{array}$ & & -0.007 & & 0.342 \\
\hline Harga Saham (Z) & & & & \\
\hline Likuiditas (X2) & & -0.013 & & 0.476 \\
\hline Profitabilitas (Y) & & 0.791 & & \\
\hline
\end{tabular}

Tabel total Effect menggambarkan pengaruh total yaitu hasil penjumlahan antara pengaruh langsung dan tidak langsung. Dari tabel di atas dapat diketahui :

1. Total pengaruh faktor eksternal ( X1 ) terhadap harga saham ( Z ) sebesar - 0,007.

2. Total pengaruh faktor eksternal ( X1 ) terhadap profitabilitas ( Y ) sebesar 0,342.

3. Total pengaruh likuiditas ( $\mathrm{X} 2$ ) terhadap harga saham $(\mathrm{Z})-0,013$.

4. Total pengaruh likuiditas ( X2 ) terhadapa profitabilitas (Y) sebesar 0,476.

5. Total pengaruh profitabilitas (Y) terhadap harga saham ( $Z$ ) sebesar 0,791. 
PEMBAHASAN

Menganalisa perbandingan rasio keuangan perusahaan industry otomotif yang terdaftar di BEI tahun 2019 ( sebelum pandemi COVID-19 ) dan tahun 2020 ( selama pandemic COVID-19)

Rasio Keuangan

Tabel 12. Perbandingan Rasio Keuangan Perusahaan Otomotif di BEI Tahun 2019 dan 2020

\begin{tabular}{|c|c|c|c|c|c|c|c|c|c|c|}
\hline $\begin{array}{l}\text { KODE } \\
\text { EMITE } \\
\mathrm{N} \\
\end{array}$ & $\begin{array}{l}\text { ROI } \\
2019\end{array}$ & $\begin{array}{l}\text { ROI } \\
2020\end{array}$ & $\begin{array}{l}\text { ROE } \\
2019\end{array}$ & $\begin{array}{l}\text { ROE } \\
2020\end{array}$ & $\begin{array}{l}\text { NPM } \\
2019\end{array}$ & $\begin{array}{l}\text { NPM } \\
2020\end{array}$ & $\begin{array}{l}\text { Curren } \\
t \text { Rasio } \\
2019 \\
\end{array}$ & $\begin{array}{l}\text { Curren } \\
t \text { Rasio } \\
2020\end{array}$ & $\begin{array}{l}\text { Cash } \\
\text { Ratio } \\
2019 \\
\end{array}$ & $\begin{array}{l}\text { Cash } \\
\text { Ratio } \\
2020 \\
\end{array}$ \\
\hline ASII & 0,076 & 0,055 & 0,143 & 0,095 & 0,112 & 0,106 & 1,291 & 1,543 & 0,243 & $\begin{array}{l}0,55 \\
5\end{array}$ \\
\hline MPMX & 0,049 & $\begin{array}{l}0,015 \\
-\end{array}$ & 0,064 & $\begin{array}{l}0,021 \\
-\end{array}$ & 0,028 & $\begin{array}{l}0,012 \\
-\end{array}$ & 2,007 & 1,540 & 1,042 & $\begin{array}{l}7 \\
0,12\end{array}$ \\
\hline IMAS & 0,003 & 0,014 & 0,017 & 0,053 & 0,008 & 0,044 & 0,775 & 0,756 & 0,065 & $\begin{array}{l}1 \\
0,22\end{array}$ \\
\hline GJTL & 0,014 & $\begin{array}{l}0,018 \\
-\end{array}$ & $\begin{array}{l}0,043 \\
-\end{array}$ & $\begin{array}{l}0,047 \\
-\end{array}$ & 0,017 & $\begin{array}{l}0,024 \\
-\end{array}$ & 1,494 & 1,605 & 0,117 & $\begin{array}{l}0 \\
0,21\end{array}$ \\
\hline GDYR & 0,002 & 0,061 & 0,005 & 0,158 & $-0,002$ & 0,066 & 0,628 & 0,657 & 0,129 & 9 \\
\hline
\end{tabular}

\section{Analisa Rasio Keuangan}

Dari data di atas dapat di jelaskan bahwa rasio profitabilitas dan likuiditas perusahaan otomotif yang terdaftar di BEI tahun 2019 dan 2020 sebagai berikut:

\section{PT.Astra International,Tbk}

Nilai $R O I$ tahun 2019 sebesar 0,076 atau 7,6 \% dan mengalami penurunan pada tahun 2020 sebesar 0,055 atau 5,5\%. ROI mengalami penurunan sebesar 2,1\%, penurunan ROI di tahun 2020 dapat disebabkan karena pendapatan dan asset yang di miliki perusahaan mengalami penurunan sehingga menyebabkan laba perusahan juga turun.Selain itu kondisi pandemic COVID-19 yang melanda dunia sehingga menyebabkan PT.Astra Internasional,tbk mengalami penurunan penjualan sehingga laba bersih juga turun. Nilai ROE tahun 2019 sebesar 0,143 (14,3\%) dan mengalami penurunan tahun 2020 sebesar $0,095(9,5 \%)$ atau mengalami penurunan sebesar $4,8 \%$. Salah satu penyebab perusahaan mengalami penurunan ROE adalah perusahaan tidak dapat menghasilkan laba atas ekuitas yang di miliki di karenakan kurangnya kemampuan perusahaan untuk memaksimalkan ekuitas. Penurunan ROE PT.Astra Internasional,Tbk disebabkan penurunan penjualan / pendapatan yang di miliki perusahaan turun sehingga laba juga turun. Nilai NPM tahun 2019 sebesar $0,112$ ( $11,2 \%$ ) dan tahun 2020 sebesar 0,106 ( $10,6 \%)$, hal ini mencerminkan jika nilai NPM lebih dari $5 \%$ maka perusahaan dapat dikatakan memiliki NPM yang baik.PT.Astra International, tbk memiliki NPM lebih dari 5\% baik tahun 2019 dan 2020.Walaupun mengalami penurunan pada tahun 2020.Hal ini terjadi karena adanya penurunan penjualan dan laba setelah pajak. Current rasio pada PT.Astra International,Tbk pada tahun 2019 sebesar 1,291 dan pada tahun 2020 sebesar 1,543.Perusahaan di katakan memiliki current rasio yang baik umumnya berkisar antara angka 1,5 dan 3. PT.Astra International,tbk mengalami kenaikan nilai current rasio pada tahun 2020 hal ini berarti perusahaan menunjukkan peningkatan kemampuan dalam hal memenuhi kewajiban lancarnya. Sedangkan nilai cash rasio tahun 2019 sebesar 0,243 dan tahun 2020 sebesar 0,555. Nilai cash rasio juga 
mengalami kenaikan, tetapi karena nilai cash rasio tidak mencapai angka 1, maka dapat dikatakan perusahaan tidak cukup memiliki kemampuan untuk membayar kewajiban jangka pendeknya.

\section{PT Mitra Pinasthika Mustika, Tbk}

Nilai ROI tahun 2019 sebesar 0,049 ( 4,9\%), sedangkan pada tahun 2020 nilai ROI sebesar 0,0015 ( $1,5 \%)$, perusahaan mengalami penurunan $R O I$, hal ini menggambarkan perusahaan mengalami penurunan tingkat laba bersih. Sedangkan untuk nilai $R O E$ tahun 2019 sebesar $0,064(6,4 \%)$ dan mengalami penurunan pada tahun 2020 sebesar 0,021 ( 2,1 \% ), hal ini menunjukan bahwa adanya pandemic COVID-19 membuat PT.Mitra Pinasthika Mustika,Tbk mengalami penurunan pendapatan sehingga menyebabkan turunnya laba bersih sehingga menyebabkan nila ROI dan ROE mengalami penurunan, Untuk nilai NPM tahun 2019 sebesar 0,028 dan tahun 2020 sebesar 0,012, hal ini menggambarkan turunnya pendapatan/penjualan dari PT.Mitra Pinasthika Mustika,Tbk. Nilai likuiditas dari perusahaan ini meliputi current rasio tahun 2019 sebesar 2,007 dan tahun 2020 sebesar 1,540 menjelaskan bahwa PT.Mitra Pinastiha Mustika,Tbk tahun 2019 memiliki kemampuan yang baik dalam hal memenuhi kewajiban lancarnya.Sedangkan pada tahun 2020 nilai current rasio mengalami penurunan sehingga dapat dikatakan perusahaan mengalami penurunan kinerja keuangan dalam hal memenuhi kewajiban lancarnya. Nilai cash rasio juga mengalami penurunan dari tahun 2019 sebesar 1,042 menjadi 0,907 pada tahun 2020 . Pada tahun 2019 perusahaan mempunyai jumlah kas yang cukup untuk membayar kewajiabannya karena mempunyai nilai cash rasio di atas 1 sedangkan pada tahun 2020 perusahaan dapat di katakana tidak memiliki cukup kas atau setara kas yang cukup untuk membayar tagihannya.

\section{PT Indomobil Sukses Indonesia,Tbk}

Pada tahun 2019 PT.Indomobil Sukses Indonesia,Tbk memiliki nilai ROI sebesar 0,003 (0,3\%) dan tahun 2020 sebesar - 0,014 (-1,4\%), nilai ROI yang rendah dan bahkan negatif pada tahun 2020 disebabkan karena perusahaan mengalami penurunan laba bersih dan total aktiva mengalami kenaikan , bahkan pada tahun 2020 perusahaan menghasilkan laba (- ). Nilai ROE tahun 2019 senilai 0,017 (1,7 \% ) dan tahun $2020-0,053(-5,3 \%)$, hal ini juga di pengaruhi karena perrusahaan mengalami penurunan laba bersih, sehingga tidak dapat mengoptimalkan ekuitas yang di miliki. Begitu pula dengan nilai NPM tahun 2019 sebesar 0,017 dan mengalami penurunan pada tahun 2020 sebesar -0,044 karena perusahaan tidak dapat menaikan nilai penjualan atau pendapatan karena dampak pandemic COVID-19.Untuk nilai rasio likuidaitas PT.Indomobil Sukses Indonesia, Tbk juga mengalami penurunan yaitu untuk current rasio dari tahun 2019 sebesar 0,775 menjadi 0,756 pada tahun 2020, hal ini dapat di katakan bahwa perusahaan tidak mempunyai nilai current rasio yang baik sehingga menyebabkan perusahaan tidak mempunyai kemampuan untuk memenuhi kewajiban lancarnya. Sedangkan nilai cash rasio pada tahun 2019 sebesar 0,065 dan tahun 2020 menjadi 0,121, nilai cash rasio mengalami kenaikan berarti menunjukkan bahwa perusahaan mempunyai peningkatan kinerja dalam hal kenaikan kas untuk membayar tagihannya walaupun belum dapat di katakana baik likuiditasnya.

\section{PT Gajah Tunggal,Tbk}

Pada tahun 2019 PT.Gajah Tunggal, tbk memiliki nilai ROI dan ROE sebesar 0,014 ( 1,4 \% ) dan 0,043 ( 4,3\% ) dan tahun 2020 nilai ROI dan ROE sebesar 0,018 ( $1,8 \%$ ) dan 0,047 ( $4,7 \%$ ). Hal ini menunjukan bahwa nilai ROI dan ROE 
mengalami kenaikan walaupun nilainya kecil yaitu 0.004 ( 0,04\%) .Kenaikan nilai ROI dan ROE di sebabkan karena perusahaan mengalami kenaikan laba bersih dan perusahaan dapat memaksimalkan asset yang di gunakan untuk operasional perusahaan. Sedangkan nilai NPM tahun 2019 sebesar 0,017 dan tahun 2020 sebesar 0,024 , nilai $N P M$ mengalami kenaikan juga. Karena adanya kenaikan laba bersih walaupun penjualan tidak mengalami kenaikan. Likuiditas PT.Gajah Tunggal ,Tbk mempunyai nilai current rasio tahun 2019 sebesar 1,494 dan tahun 2020 sebesar 1,605. Sedangkan nilai cash rasio tahun 2019 sebesar 0,117 dan tahun 2020 0,220. Hal ini menunjukkan bahwa PT.Gajah Tunggal,Tbk mempunyai kenaikan dalam hal membayar kewajibannya lancarnya walaupun belum dapat di katakana likuid karena nilai current rasionya masih di bawah 2,0. Untuk cash rasio perusahaan mempunyai kenaikan kas sehingga perusahaan mempunyai kas atau setara kas untuk dapat membayar kewajiban jangka pendeknya.

\section{PT Goodyear Indonesia ,Tbk}

Nilai ROI, ROE,NPM PT Goodyear Indonesia,Tbk tahun 2019 adalah -0,002 ( $0,2 \%),-0,005(-0,5 \%),-0,002(-0,02 \%)$ dan nilai tahun 2020 adalah $-0,061$ (0,61\%), $-0,158$ ( $-15,8 \%),-0,066(-6,6 \%)$. Rasio profitabilitas dari PT.Goodyear Indonesia,Tbk baik tahun 2019 dan 2020 memiliki nilai negatif,hal ini dapat di artikan bahwa perusahaan memiliki laba negatif atau rugi tetapi perusahaan masih bisa bertahan karena kemungkinan masih adanya piutang yang belum di bayar. Untuk nilai rasio likuiditas nya PT.Goodyear Indonesia,Tbk adalah pada tahun 2019 nilai current rasio dan cash rasio sebesar 0,630 dan 0,129. Sedang di tahun 2020 nilai current rasio dan cash rasio adalah 0,66 dan 0,219. Nilai rasio likuiditas perusahaan mengalami kenaikan walaupun nilainya kecil tetapi belum dapat di katakan likuid. Tetapi ini merupakan hal yang bagus bagi kinerja perusahaan karena adanya peningkatan perusahaan dalam hal memenuhi kewajiban lancar dan kewajiban jangka pendeknya.

\section{Analisa Dampak Pandemi COVID-19 Terhadap Kinerja Perusahaan Otomotif Yang Terdaftar Di BEI}

Dilihat dari kinerja perusahaan otomotif yang di jadikan sampel tahun 2019 rata-rata sudah menunjukan kinerja yang kurang baik karena dari 5 perusahaan yang di teliti hampir secara keseluruhan memiliki nilai rasio profitabilitas dan rasio likuiditas yang masih di bawah standar untuk bisa di kategorikan baik.Setelah adanya pandemi COVID-19 yang pada awalnya mengharuskan semua perusahaan otomotif menghentikan operasional nya dan adanya beberapa kebijakan yang akhirnya berdampak bagi industri otomotif, di antaranya penurunan penjualan, penurunan laba bersih dan pemakaian asset untuk operasional perusahaan. Pada tahun 2020, kinerja perusahaan otomotif rata-rata mengalami penurunan, hal ini dapat di lihat dari turunnya nilai rasio profitabilitaas dan likuiditas. Kecuali untuk PT.Gajah Tunggal, Tbk , rasio profitabilitas dan likuiditasnya mengalami kenaikan walaupun tidak signifikan. Jadi dapat di katakan dengan adanya pandemi COVID-19 ini, kinerja perusahaan otomotif mengalami penurunan dan bahkan mengakibatkan perusahaan mengalami kerugian ( laba negatif ).

\section{Simpulan/Conclusion}

Kesimpulan yang di peroleh dari penelitian ini adalah sebagai berikut:

1. Faktor eksternal, dalam hal ini inflasi dan suku bunga berpengaruh positif signifikan terhadap profitabilitas perusahaan otomotif yang terdaftar di BEI, hal ini menunjukkan bahwa perubahan inflasi dan suku bunga mempunyai pengaruh terhadap perubahan 
profitabilitas,

2. Likuiditas berpengaruh positif signifikan terhadap profitabilitas perusahaan otomotif yang terdaftar BEI, pengaruh positif signifikan menunjukkan bahwa kemampuan perusahaan dalam memenuhi kewajiban jangka pendeknya semakin tinggi, maka semakin tinggi aktiva lancar yang di miliki perusahaan, maka perusahaan semakin likuid yang berarti dapat membayar hutang jangka panjangnya. Pengaruh signifikan mengindikasikan bahwa investor akan memperoleh profitabilitas yang tinggi jika perusahaan memiliki likuiditas (kemampuan memenuhi kewajiban jangka pendeknya) tinggi.

3. Profitabilitas berpengaruh positif signifikan terhadap harga saham perusahaan otomotif yang terdaftar di BEI, pengaruh positif signifikan menunjukkan jika profitabilitas mengalami perubahan ( naik atau turun ) maka harga saham juga akan mengalami perubahan. Hal ini dapat di artikan bahwa dengan memaksimalkan penggunaan aktiva yang di miliki perusahaan untuk menghasilkan laba maka akan meningkatkan nilai perusahaan berupa meningkatnya harga saham.

4. Faktor eksternal berpengaruh negatif dan tidak signifikan terhadap harga saham perusahaan otomotif yang terdaftar di BEI, jadi faktor eksternal dalam hal ini inflasi dan suku bunga memiliki hubungan yang tidak searah yaitu jika faktor eksternal ( inflasi, suku bunga ) naik maka harga saham akan mengalami penurunan begitu sebaliknya.

5. Likuiditas berpengaruh negatif signifikan terhadap harga saham pada perusahaan otomotif yang terdaftar di BEI, hal ini menandakan hubungan yang tidak searah, yaitu jika likuiditas naik maka harga saham akan turun dan sebaliknya jika likuiditas turun maka harga saham akan naik.Dengan kata lain kemampuan perusahaan dalam membayar hutang lancar dengan menggunakan aktiva lancar tidak maksimal, yang artinya variabel likuiditas tidak mampu di gunakan untuk memprediksi harga saham di masa yang akan datang.

6. Kinerja keuangan perusahaan otomotif yang terdaftar di BEI, mengalami penurunan secara keseluruhan akibat pandemic COVID-19, jika sebelum pandemi rata-rata perusahaan mengalami kinerja yang cukup baik, tetapi dengan adanya pandemi COVID-19, kinerja perusahaan otomotif mengalami penurunan. Penurunan tingkat penjualan yang signifikan sehingga mengakibatkan penurunan laba bersih.

\section{Implikasi Manajerial}

Dengan adanya dampak pandemi COVID-19 pertumbuhan ekonomi di Indonesia mengalami penurunan yang signifikan sehingga menyebabkan penurunan daya beli atau konsumsi masyarakat. Industri otomotif juga mengalami pukulan berat karena menurunnya daya beli masyarakat terhadap otomotif, mereka lebih memilih untuk bertahan di tengah pandemi di bandingkan untuk membeli kendaraan. Melihat kondisi seperti ini pemerintah melakukan beberapa stimulus terhadap industri otomotif, karena industri otomotif merupakan salah satu sektor andalan yang memiliki konstribusi yang cukup besar terhadap perekonomian nasional. Beberapa stimulus yang di lakukan pemerintah antara lain:

1. Menghadirkan pameran otomotif secara virtual IIMS (Indonesia International Motor Show) yang menjadikan salah satu ajang untuk memperkenalkan teknologi terbaru dari industri otomotif di tanah air.I

2. Terbitnya PMK 20/PMK.010/ 2021 tentang Penjualan Atas Barang Mewah Atas Penyerahan Kena Pajak yang Tergolong mewah berupa Kendaraan Bermotor Tertentu yang di tanggung oleh Pemerintah tahun anggaran 2021. Kebijakan penghapusan PPn BM ini di harapkan dapat meningkatkan produksi dan penjualan 
di sektor industri otomotif.

3. Pemerintah melakukan kebijakan kesehatan yang komprehensif ( program vaksinasi yang di harapakan dapat menstimulus fiskal untuk mendorong daya beli masyarakat.

Sedangkan implikasi manajerial bagi perusahaan industri otomotif antara lain :

1. Untuk menjaga likuiditas perusahaan industri otomotif, perusahaan melakukan ekspansi bisnis,seperti mencoba melakukan bisnis di bidang penanganan COVID-19 ( missal laboratorium untuk pemeriksaan COVID-19)

2. Menurunkan biaya produksi dengan menerapkan system produksi rampin ( lean Saran manufacturing ) dan pengelolaan logistic yang efektif dan efisien.

1. Untuk investor, sebaiknya sebelum mengambil keputusan untuk menginvestasikan dananya ke saham sebuah perusahaan, sebaiknya memperhatikan tingkat faktor eksternal, likuiditas, dan profitabilitas sebagai faktor yang mempengaruhi harga saham.

2. Untuk perusahaan, sebaiknya pihak manajemen dapat meningkatkan kinerja keuangan maupun kinerja manajemen secara keseluruhan walaupun masih pada masa pandemic COVID-19. Strategi apa saja yang dapat di lakukan perusahaan untuk dapat menaikkan penjualannya di masa pandemic COVID-19.

3. Untuk penelitian berikutnya, dapat memasukkan tax amnesty sebagai salah satu variabelnya, mengingat pada masa pandemic COVID-19, pemerintah memberikan tax amnesty kepada perusahaan.

\section{Daftar Pustaka}

Amri, A., \& Ramdani, Z. (2020). Pengaruh nilai tukar, kebijakan deviden dan struktur modal terhadap return saham pada perusahaan yang terdaftar di jakarta islamic index. Jurnal Ilmu Keuangan Dan Perbankan (JIKA), 10(1), 17-36. https://doi.org/10.34010/JIKA.V10I1.3556

Amri, A., Widyastuti, T., Bahri, S., \& Ramdani, Z. (2021). Apakah benar kecerdasan spiritual itu menentukan perilaku manajemen keuangan seseorang? Perspektif mahasiswa pascasarjana. Jurnal Perspektif, 5(1), 1-13.

BPS. (2021). Kenaikan tingkat kemiskinan selama pandemi COVID-19. Badan Pusat Statistik. www.bps.go.id\%0A

Rahmadewi, P. W., \& Abundanti, N. (2018). PENGARUH EPS, PER, CR, DAN ROE TERHADAP HARGA SAHAM DI BURSA EFEK INDONESIA. 7(4), 2106-2133. https://doi.org/10.24843/EJMUNUD.2018.v7.i04.p14

Ramadhi, Amri, A., \& Ramdani, Z. (2021). Studi terhadap faktor-faktor yang menentukan kinerja seorang karyawan. Jurnal Sains Manajemen, 7(2), 129-143.

Brigham, Eugene F., dan Joel F. Houston. 2010. Dasar-dasar Manajemen

Keuangan: Essential of Financial Management, Edisi 11, Buku 1, Salemba Empat : Jakarta.

Fahmi, Irfan. 2012. Analisis Laporan Keuangan. Cetakan ke-2. Alfabeta. Bandung

Horne, James C. Van, dan John M. Wachowicz, Jr. 2012. Prinsip-prinsip Manajemen Keuangan, Buku 1, Edisi 12, Salemba Empat : Jakarta.

Kasmir. 2014. Analisis Laporan Keuangan, Edisi Pertama, Cetakan Ketujuh. PT. Rajagrafindo Persada. Jakarta.

Keown AJ, Martin JD, Petty JW, Scott DF. 2016. Manajemen Keuangan: Prinsip dan Penerapan. Edisi Kesepuluh Jilid 2. Widodo MP, penerjemah; Indriani, editor. Jakarta (ID) : Indeks. Terjemahan dari: Financial Management: Principles and Applications.

Krismiaji. 2016. Dasar-Dasar Akuntansi Manajemen. AMP YKPN. Yogyakarta. 
Munawir. 2017. Analisa Laporan Keuangan. Liberty. Yogyakarta.

Pramastuti, Suluh, 2017, Analisis Kebijakan Dividen : Pengujian Dividend

Signaling Theory dan Rent Extraction Hypothesis, Tesis, Universitas Gajah Mada : Yogyakarta.

SarOunceo, Agus. 2015. Manajemen Keuangan Teori dan Aplikasi, Edisi 4, Cetakan Pertama, BPFE : Yogyakarta.

Sawir, Agnes, 2012, Analisis Kinerja Keuangan dan Perencanaan Keuangan

Perusahaan, PT. Gramedia Pustaka Utama : Jakarta.

Sugiyono. 2016. Metode Penelitian Pendidikan (Pendekatan Kuantitatif,

Kualitatif, dan R\&D).Bandung: Alfabeta.

Syahyunan. 2015. Manajemen Keuangan - Perencanaan, Analisis dan

Pengendalian Keuangan, USU Press : Medan.

Syamsudin, L. (2009). Manajemen Keuangan Perusahaan. Jakarta: Raja GrafindoPersada.

$\underline{\text { Jurnal }}$

Anjas Kusumadewi. 2014. Pengaruh Likuiditas dan Profitabilitas terhadap Harga Saham Perusahaan Manufaktur yang terdaftar di BEI Periode 2010 -2013.Universitas Dian Nuswantoro

Semarang Jurnal .

Elvin Ruswanda Yudistira, I Made Pradana Adiputra.2020. Pengaruh Faktor Internal dan Eksternal Terhadap HArga Saham . Universitas Pendidikan Ganesha Bali.

Denies Priatinah,Prabandaru Adhe Kusuma . 2012. Pengaruh Return on Investment (ROI), Earning Per Share ( EPS) dan Dividen Per Share (DPS) terhadap Harga Saham. Universitas Negeri Yogyakarta

Abdul Karim. 2015 Analisis Pengaruh Faktor Internal dan Eksternal Terhadap Return Saham Perusahaan Manufaktur Yang Terdaftar di Bursa Efek Indonesia (BEI) Periode 2010-2012.

Ridhwan. 2016 Analisis Pengaruh Suku Bunga dan Inflasi Terhadap Profitabilitas PT.Bank Syariah Mandiri Indonesia.

\section{$\underline{\text { Internet }}$}

[BPS] Badan Pusat Statistik. 2019 dan 2020. Nilai Suku Bunga. [diunduh 2021 Juli 1].Tersedia pada : https://www.bps.go.id/statictable/2019/02/27/2034/

[BEI] Bursa Efek Indonesia . 2019. Laporan Keuangan dan Tahunan [internet]. Jakarta (ID): BEI. [diunduh 2021 Juli 4]. Tersedia pada: http://www.idx.co.id

[BEI] Bursa Efek Indonesia . 2020. Laporan Keuangan Triwulan dan Tahunan [internet]. Jakarta (ID): BEI. [diunduh 2021 Juli 4]. Tersedia pada: http://www.idx.co.id

[BankIndonesia].2020.SukuBunga Jakarta [diunduh 2021 Juli 7] Tersedia pada:https://www.bi.go.id/id/search.aspx\#k=suku\%20bunga 